\title{
SELECTED ISSUES REGARDING THE RELIABILITY-OPERATIONAL ASSESSMENT OF ELECTRONIC TRANSPORT SYSTEMS WITH REGARD TO ELECTROMAGNETIC INTERFERENCE
}

\section{WYBRANE ZAGADNIENIA OCENY NIEZAWODNOŚCIOWO-EKSPLOATACYJNEJ TRANSPORTOWYCH SYSTEMÓW ELEKTRONICZNYCH Z UWZGLĘDNIENIEM ZAKŁÓCEŃ ELEKTROMAGNETYCZNYCH*}

\begin{abstract}
The article presents issues associated with the reliability-operational analysis of electronic transport systems, which are operated in a defined environment. Intended or unintended (static or mobile) electromagnetic interference, which are present over a broad transport area, can cause interference of its functioning. That is why correct functioning of electronic transport systems in a distorted electromagnetic environment is so important. The articles measurement results of low frequency radiation basic characteristics for power supplies, which were carried out for two frequency ranges: $(0 \div 400) \mathrm{Hz}$ and $(400 \div 6500) \mathrm{Hz}$. The impact of the load's voltage change on the electric field $E[\mathrm{~V} / \mathrm{m}]$ produced by the power supply and the impact of power supply load's current changes on the induction of the magnetic field B [nT] were presented. Next, a graph of relations in an electronic transport system, with regard to level of interference in electric and magnetic fields, was developed. This allowed to determine the relations, which enable to define the probability values of a system being in the distinguished states. The methodology of the reliability-operational analysis of electronic transport systems with regard to electromagnetic interference presented in this article, may be used during designing of electronic systems used in transport.
\end{abstract}

Keywords: operation, reliability, electromagnetic interference, electronic transport systems.

W artykule przedstawiono zagadnienia zwiazane z analiza niezawodnościowo-eksploatacyjna transportowych systemów elektronicznych, które sq eksploatowane w określonym środowisku. Wystęujace na rozległym obszarze transportowym zaburzenia elektromagnetyczne zamierzone lub niezamierzone (stacjonarne lub ruchome) moga być przyczyna zaktócenia ich funkcjonowania. Dlatego tak istotne jest prawidlowe funkcjonowanie transportowych systemów elektronicznych $w$ zniekształconym środowisku elektromagnetycznym. W artykule przedstawiono wyniki pomiarów podstawowych charakterystyk promieniowania niskiej czę-

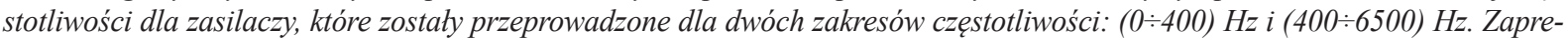
zentowano wpływ zmiany napięcia obciążenia na pole elektryczne $E[\mathrm{~V} / \mathrm{m}]$ wytwarzane przez zasilacz, oraz wphyw zmiany prądu obciażenia zasilacza na indukcje pola magnetycznego B [nT]. Następnie opracowano graf relacji w transportowym systemie elektronicznym z uwzględnieniem poziomów zakłóceń pola elektrycznego i magnetycznego. Umożliwiło to wyznaczenie zależności pozwalających na określenie wartości prawdopodobieństw przebywania systemu w wyróżnionych stanach. Zaprezentowana w artykule metodyka analizy niezawodnościowo-eksploatacyjnej transportowych systemów elektronicznych z uwzględnieniem zaktóceń elektromagnetycznych może być użyta podczas projektowania systemów elektronicznych stosowanych w transporcie.

Stowa kluczowe: eksploatacja, niezawodność, zakłócenia elektromagnetyczne, transportowe systemy elektroniczne.

\section{Introduction}

Electronic transport systems function in different, often extreme, operational conditions. Many years of observations of their use process in a transport environment confirm the dependence of their correct operation on the reliability of the components and effective management of their operation process $[6,7,8]$. The analysis of operational phenomena should, therefore, take into account not only the reliability approach but also the effectiveness of operational management. For this purpose, the authors imitated the phenomena undergoing in reality (including electromagnetic interference) in a research model of an electronic transport system.

Electronic transport systems are elements in many transport systems. Their proper functioning significantly impacts the safety and efficiency of the process of transporting humans and cargo. Unreliability of electrical equipment and operator errors may lead to safety hazard states $[11,15,18,30]$. The theory of unreliability deals with the analysis of the impact of equipment damage and operator errors on defined unreliability indicators $[24,26]$. The scope of interest of the theory of safety are the results of damages and errors, which lead to safety hazards. Very important is the issue of correct determination which of the system's states can be deemed permissible or impermissible, from the safety point of view.

The safety hazard state may be a reversible state, when there is a possibility to take actions aimed at restoring the state of full worthiness (e.g. Diagnosing a damage and attempting repair, correcting an operator error, neutralising an external event). The

(*) Tekst artykułu w polskiej wersji językowej dostępny w elektronicznym wydaniu kwartalnika na stronie www.ein.org.pl 
execution of a counter-action has to be performed in the availability time. In case of the counter-action being ineffective or is taking too long, the system switches from the safety hazard state to a hazard state, also called the safety unreliability state.

An increase of the level of electronic transport systems' safety may be executed through improving their reliability parameters. An increase in reliability can be achieved by the increased reliability of components or using redundant structures [20, 21, 25, 32]. The first solution is aimed at preventing damages. In the second case, the use of double or triple redundancy leads to, admittedly, expansion of the system but enables tolerating the occurring damages. Redundancy may concern the devices subassemblies, system modules, as well as e.g. computers controlling transport processes. The quality of information $[10,28,29]$, which the systems receive from sensors is also important $[4,9]$. Some scientific papers propose to use fuzzy logic [27] or artificial neuron networks [5]. Electronic transport systems are also significantly impacted by vibrations [2] but they are not taken into consideration in this article.

Electronic transport systems operate in various operating conditions present in transport areas. Their correct functioning is conditioned not only on the reliability of individual components comprising the system but also on the level of electromagnetic interference [12, 14] and the operational strategies adopted for implementation

The article presents measurements of the electromagnetic spectrum, which was created as a result of the use of power supplies used in electronic transport systems. An analysis of the obtained results made it possible to develop a research model of an electronic transport system and then, to carry out the reliability-operational analysis with regard to electromagnetic interference.

\section{Electronic transport systems}

Mutual coexistence of electronic transport systems and their correct functioning in the transport domain in a defined electromagnetic environment and the functioning without introducing unacceptable electromagnetic interference into that environment, can be defined as electromagnetic compatibility $[1,3,13]$.

In the case of the impact of electromagnetic interference on electronic transport systems, we can distinguish four operating states for these systems:

- the system does not react to external and internal interference - the interference level is too low, permissible interference levels were not exceeded, the system remains in a given operating state in which it currently is,

- the devices comprising the control system automatically remove interference through used passive or active filters, screening, correct distribution or system solutions,

- the occurrence of interference with values not exceeding the permissible ones, causes the system to switch from the worthiness state to the partial worthiness states - restoration of the worthiness state requires taking specific actions,

- the occurrence of interference with values exceeding the permissible ones, damages the system, and thus, the transition from the worthiness to the unworthiness state.

Electronic transport systems are installed in stationary and mobile facilities, and are used in a defined electromagnetic environment. Natu- ral electromagnetic environment is shaped by the phenomena that occur on the ground, but is seriously distorted on the transport area. One of the reasons for that is the presence of a high number of electromagnetic fields, radiating in intended or unintended manners. Each electric or electronic device, supplied with electric power, produces its own electromagnetic field, which is associated with its operation [22, 23]. Electronic devices and systems, supplied by feeders of different types, are used over the transport area. They should function properly, regardless of the present interference, which have effect on them.

Electromagnetic interference with a broad frequency band, generated by different devices used over the transport area simultaneously, at the same time impact the electronic transport systems. The interference signal spectrum results from the operating frequency of systems (devices), their harmonics and the intermodulation frequencies, which are the result of non-linearity, e.g. of electronic elements.

Modern electronic transport systems used, i.a., in transport, are expected to satisfy many requirements. They can include, i.a., miniaturization, limited electrical energy consumption, high reliability. Introducing these limitations may result in the fact that the level of useful signals from devices may be comparable to the level of interference generated by, e.g., stationary and mobile interference sources (e.g. base and radio stations, MV and LV lines, transformer stations, commonly use electrical devices). That is why, it is necessary to perform a reliability-operational analysis of the systems, with regard to electromagnetic interference.

\section{Reliability-operational analysis of electronic trans- port systems with regard to electromagnetic interfer- ence}

In order to measure the low frequency radiation characteristics of power feeders of electronic transport systems, a spectrum analyser, with an operating frequency of $0 \mathrm{~Hz}$ to $100 \mathrm{kHz}$, was used. The radiation spectrum in the low frequency range, and this was adopted for the device functional analysis, is divided into two sub-ranges: ELF and VLF. Observing the changes of individual spectrum components radiated by the power supplies, their operating state can be characterized.

The measurement of the low frequency radiation basic characteristics was carried out for two frequency ranges: $(0 \div 400) \mathrm{Hz}$ and $(400 \div 6500) \mathrm{Hz}$. A measurement above the frequency of $6.5 \mathrm{kHz}$ is of little usefulness from the point of view of the device's diagnostics, since particular components of the electromagnetic field radiation have very small values. Tables 1 and 2 present the impact of the load's voltage change on the electric field $\mathrm{E}[\mathrm{V} / \mathrm{m}]$ produced by the power supply and the impact of power supply load's current changes on the induction of the magnetic field B [nT]. The E, B components

Table 1. Electrical field $E[\mathrm{~V} / \mathrm{m}]$ produced by tested power supplies for individual signal spectrum components (load current constant, change of the output voltage for a given power supply type)

\begin{tabular}{|c|c|c|c|c|c|c||}
\hline Power supply type & \multicolumn{2}{|c|}{ P339 } & \multicolumn{2}{c|}{ BS525 } & \multicolumn{2}{c||}{5353} \\
\hline Frequency [Hz] & U=10V I=3A & U=20V I=3A & U=15V I=1A & U=30V I=1A & $\begin{array}{l}\text { U=20V } \\
\text { I=1,8A }\end{array}$ & $\begin{array}{l}U=48 V \\
\text { I=1,8A }\end{array}$ \\
\hline 50 & 1,603 & 1,799 & 1,71 & 2,64 & 1,628 & 2,277 \\
\hline 100 & 0,0053 & 0,0058 & 0,0062 & 0,0073 & 0,003 & 0,003 \\
\hline 150 & 0,174 & 0,241 & 0,174 & 0,34 & 0,16 & 0,21 \\
\hline 350 & 0,13 & 0,18 & 0,1294 & 0,14 & 0,12 & 0,22 \\
\hline 1250 & 0,173 & 0,18 & 0,0196 & 0,021 & 0,016 & 0,015 \\
\hline
\end{tabular}


Table 2. Induction of the magnetic field B [nT] produced by tested power supplies for individual signal spectrum components (load voltage constant, change of the output current for a given power supply type)

\begin{tabular}{|c|c|c|c|c|c|c||}
\hline \multirow{2}{*}{ Power supply type } & \multicolumn{2}{|c|}{ P339 } & \multicolumn{2}{c|}{ BS525 } & \multicolumn{2}{c||}{5353} \\
\hline Frequency [Hz] & U=10V I=1A & U=10V I=4A & U=30V I=0,5A & U=30V I=1A & U=48V I=0,5A & U=48V I=1,8A \\
\hline 50 & 1834,25 & 1883,65 & 3556,3 & 4358,6 & 2540,9 & 2851,02 \\
\hline 100 & 527,84 & 901,57 & 53 & 109,5 & 44,8 & 125,9 \\
\hline 150 & 5134,52 & 4623,81 & 188 & 590 & 512,9 & 575,4 \\
\hline 250 & 845,28 & 1096,48 & 169 & 199,8 & 46,1 & 316,3 \\
\hline 350 & 134,74 & 121,62 & 42,5 & 467,4 & 14,2 & 50,2 \\
\hline 550 & 4,47 & 13,96 & 1,7 & 4,6 & 2,99 & 5,7 \\
\hline
\end{tabular}

of the electromagnetic field are produced in an unintended way by the tested power supplies of the electronic transport systems. In order to determine the impact of the am parameters (load current, output voltage) of the system's power supply, a measurement stand for measuring diffused fields E, B produced by the tested devices was developed and constructed.

When testing the impact of load voltage on the spectrum of an electromagnetic field, the increase of signal spectrum harmonics component amplitude can be noticed for particular power supply types (tab. 1). For the P339 power supply, the biggest impact was noticed for the $150 \mathrm{~Hz}$ harmonics - the value of $0.174 \mathrm{~V} / \mathrm{m}$ increased to 0.241 $\mathrm{V} / \mathrm{m}$, with the increase of the supply voltage from $10 \mathrm{~V}$ to $20 \mathrm{~V}$. Also for the power grid's component frequency of $50 \mathrm{~Hz}$ there was an increase of amplitude, but it was smaller and amounted to only $10.89 \%$. For the remaining power supplies, an increase of the amplitude of individual harmonics, together with an increase of the supply voltage, can also be noticed. The biggest increase was for the frequency of $100 \mathrm{~Hz}$, for the BS525 power supply and amounted to $48.8 \%$. For higher frequencies (above $350 \mathrm{~Hz}$ ), individual field components with the change of the supply load voltage, did not have high amplitude values. The increase of the amplitude values was very small, together with the increase of the load voltage.

A similar phenomenon of the increase in the amplitude of electromagnetic field's individual harmonics can be observed for magnetic field B induction. An increase of the field's induction was noticed during the increase of the load current drawn from a power supply (tab. 2). A significant increase of the harmonics amplitude of the

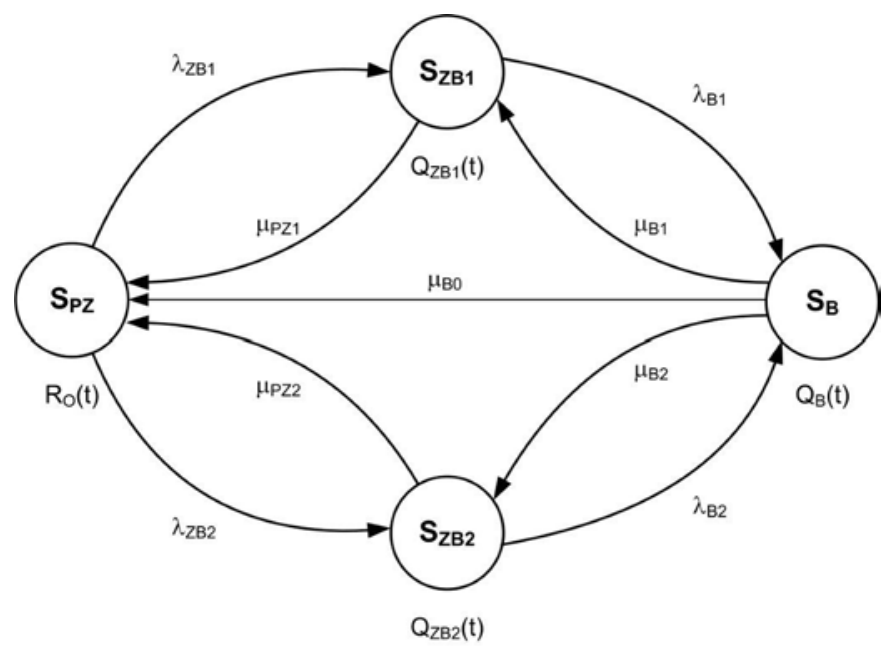

Fig. 1. Relations in an electronic transport system electromagnetic field can be observed for higher frequencies, i.e., 250, 350, $550 \mathrm{~Hz}$. For the frequency of $350 \mathrm{~Hz}$, the increase of the harmonics amplitude for the BS525 power supply was as much as $90.9 \%$. However, with the increase of the load current, increases of individual negative harmonics were also observed. This phenomenon, i.a., can be associated with returning the field's energy from some spectrum bands to others. By thoroughly studying the increase of magnetic field's B induction and electric field's E current, we can obtain information about the state of the power supply load's current and voltage.

Analysing the obtained results, we can conclude that an electronic transport system (operated in a transport environment, with electromagnetic interference present) can be in the distinguished states [19, 31]. Therefore, the idea to carry out the reliability-operational analysis seems reasonable. Thanks to that, we will obtain relations, which allow to determine the probability values of the system being in the distinguished operational states

By conducting the reliability and exploitation analysis of the electronic transport system, it is possible to illustrate the relationships in it, as shown in Figure 1.

\section{Denotations in figures:}

$R_{O}(t)$ - the function of probability of system staying in state of full ability $\mathrm{S}_{\mathrm{PZ}}$,

$\mathrm{Q}_{\mathrm{ZB} 1}(\mathrm{t})-$ the function of probability of system staying in state of the impendency over safety $\mathrm{S}_{\mathrm{ZB} 1}$,

$\mathrm{Q}_{\mathrm{ZB} 2}(\mathrm{t})$-the function of probability of system staying in state of the impendency over safety $\mathrm{S}_{\mathrm{ZB} 2}$,

$Q_{B}(t)$ - the function of probability of system staying in state of unreliability of safety $S_{B}$,

$\lambda_{\mathrm{ZB} 1}$ - transition rate from the state of full ability $\mathrm{S}_{\mathrm{PZ}}$ into the state of the impendency over safety $\mathrm{S}_{\mathrm{ZB} 1}$,

$\lambda_{\mathrm{ZB} 2}-$ transition rate from the state of full ability $\mathrm{S}_{\mathrm{PZ}}$ into the state of the impendency over safety $\mathrm{S}_{\mathrm{ZB} 2}$,

$\mu_{\mathrm{PZ1}}-$ transition rate from the state of the impendency over safety $\mathrm{S}_{\mathrm{ZB} 1}$ into the state of full ability $\mathrm{S}_{\mathrm{PZ}}$,

$\mu_{\mathrm{PZ2} 2}-$ transition rate from the state of the impendency over safety $\mathrm{S}_{\mathrm{ZB} 2}$ into the state of full ability $\mathrm{S}_{\mathrm{PZ}}$,

$\lambda_{\mathrm{B} 1}-$ transition rate from the state of the impendency over safety $\mathrm{S}_{\mathrm{ZB} 1}$ into the state of unreliability of safety $\mathrm{S}_{\mathrm{B}}$,

$\lambda_{\mathrm{B} 2}-$ transition rate from the state of the impendency over safety $\mathrm{S}_{\mathrm{ZB} 2}$ into the state of unreliability of safety $\mathrm{S}_{\mathrm{B}}$,

$\mu_{\mathrm{B} 1}-$ transition rate from the state of unreliability of safety $S_{B}$ into the state of the impendency over safety $\mathrm{S}_{\mathrm{ZB} 1}$,

$\mu_{\mathrm{B} 2}-$ transition rate from the state of unreliability of safety $\mathrm{S}_{\mathrm{B}}$ into the state of the impendency over safety $\mathrm{S}_{\mathrm{ZB} 2}$,

$\mu_{\mathrm{B} 0}-$ transition rate from the state of unreliability of safety $\mathrm{S}_{\mathrm{B}}$ into the state of full ability $\mathrm{S}_{\mathrm{PZ}}$.

Full worthiness state $S_{P Z}$ is a state, in which the electronic transport system functions correctly. The safety hazard state $\mathrm{S}_{\mathrm{ZB} 1}$ is a state, in which the electronic transport system is partially fit for use (interference of the electric field do not exceed permissible values) The safety hazard state $\mathrm{S}_{\mathrm{ZB} 2}$ is a state, in which an electronic 
transport system is partially fit for use (interference of the magnetic field do not exceed permissible values) The safety hazard state $S_{B}$ is a state, in which the electronic transport system is unfit for use (interference of the electric and magnetic fields exceed permissible values).

If an electronic transport system is in a state of full worthiness $\mathrm{S}_{\mathrm{PZ}}$ and there appears an electric field interference, then it switches to the safety hazard state $S_{\mathrm{ZB} 1}$ with the intensity $\lambda_{\mathrm{ZB} 1}$. If the system is in the safety hazard state $S_{Z B 1}$, then it is possible to switch to the full worthiness state $\mathrm{S}_{\mathrm{PZ}}$, provided that actions are taken aimed at restoring the worthiness state.

In case of a safety hazard state $\mathrm{S}_{\mathrm{ZB} 1}$ and additionally, there appears an interference of the magnetic field, then the system switches to the safety unreliability state $S_{B}$ with the intensity $\lambda_{B 1}$. Return transition of the safety hazard state $S_{Z B 1}$ from the safety unreliability state $S_{B}$ is possible, provided actions are taken, aimed at mitigating the level of magnetic field interference, to a value in the permissible range.

If an electronic transport system is in a state of full worthiness $S_{P Z}$ and there appears a magnetic field interference, then it switches to the safety hazard state $\mathrm{S}_{\mathrm{ZB} 2}$ with the intensity $\lambda_{\mathrm{ZB} 2}$. If the system is in the safety hazard state $\mathrm{S}_{\mathrm{ZB} 2}$, then it is possible to switch to the full worthiness state $\mathrm{S}_{\mathrm{PZ}}$, provided that actions are taken aimed at restoring the worthiness state.

In case of a safety hazard state $\mathrm{S}_{\mathrm{ZB} 2}$ and additionally, there appears an interference of the electric field, then the system switches to the safety unreliability state $S_{B}$ with the intensity $\lambda_{B 2}$. Return transition of the safety hazard state $\mathrm{S}_{\mathrm{ZB} 2}$ from the safety unreliability state $S_{B}$ is possible, provided actions are taken, aimed at mitigating the level of electric field interference, to a value in the permissible range.

If an electronic transport system is in the safety unreliability state $S_{B}$ and there are interference in the magnetic and electric fields, then the system switches to the full worthiness state $\mathrm{S}_{\mathrm{PZ}}$ with the intensity $\mu_{\mathrm{B} 0}$.

The system illustrated in fig. 1 may be described by the following Chapman-Kolmogorov equations:

$$
\begin{aligned}
& R_{0}^{\prime}(t)=-\lambda_{Z B 1} \times R_{0}(t)+\mu_{P Z 1} \times Q_{Z B 1}(t)-\lambda_{Z B 2} \times R_{0}(t)+\mu_{P Z 2} \times Q_{Z B 2}(t)+\mu_{B 0} \times Q_{B}(t) \\
& Q_{Z B 1}^{\prime}(t)=\lambda_{Z B 1} \times R_{0}(t)-\mu_{P Z 1} \times Q_{Z B 1}(t)-\lambda_{B 1} \times Q_{Z B 1}(t)+\mu_{B 1} \times Q_{B}(t) \\
& Q_{Z B 2}^{\prime}(t)=\lambda_{Z B 2} \times R_{0}(t)-\mu_{P Z 2} \times Q_{Z B 2}(t)-\lambda_{B 2} \times Q_{Z B 2}(t)+\mu_{B 2} \times Q_{B}(t) \\
& Q_{B}^{\prime}(t)=\lambda_{B 1} \times Q_{Z B 1}(t)+\lambda_{B 2} \times Q_{Z B 2}(t)-\mu_{B 0} \times Q_{B}(t)-\mu_{B 1} \times Q_{B}(t)-\mu_{B 2} \times Q_{B}(t)
\end{aligned}
$$

Given the initial conditions:

$$
\begin{aligned}
& R_{0}(0)=1 \\
& Q_{Z B 1}(0)=Q_{Z B 2}(0)=Q_{B}(0)=0
\end{aligned}
$$
tions:

Laplace transform yields the following system of linear equa-

$$
\begin{aligned}
& s \times R_{0}^{*}(s)-1=-\lambda_{Z B 1} \times R_{0}^{*}(s)+\mu_{P Z 1} \times Q_{Z B 1}^{*}(s)-\lambda_{Z B 2} \times R_{0}^{*}(s)+\mu_{P Z 2} \times Q_{Z B 2}^{*}(s)+\mu_{B 0} \times ! \\
& s \times Q_{Z B 1}^{*}(s)=\lambda_{Z B 1} \times R_{0}^{*}(s)-\mu_{P Z 1} \times Q_{Z B 1}^{*}(s)-\lambda_{B 1} \times Q_{Z B 1}^{*}(s)+\mu_{B 1} \times Q_{B}^{*}(s) \\
& s \times Q_{Z B 2}^{*}(s)=\lambda_{Z B 2} \times R_{0}^{*}(s)-\mu_{P Z 2} \times Q_{Z B 2}^{*}(s)-\lambda_{B 2} \times Q_{Z B 2}^{*}(s)+\mu_{B 2} \times Q_{B}^{*}(s) \\
& s \times Q_{B}^{*}(s)=\lambda_{B 1} \times Q_{Z B 1}^{*}(s)+\lambda_{B 2} \times Q_{Z B 2}^{*}(s)-\mu_{B 0} \times Q_{B}^{*}(s)-\mu_{B 1} \times Q_{B}^{*}(s)-\mu_{B 2} \times Q_{B}^{*}(s)
\end{aligned}
$$

Probabilities of system staying in a distinguished functional states in symbolic (Laplace) terms have the following form:

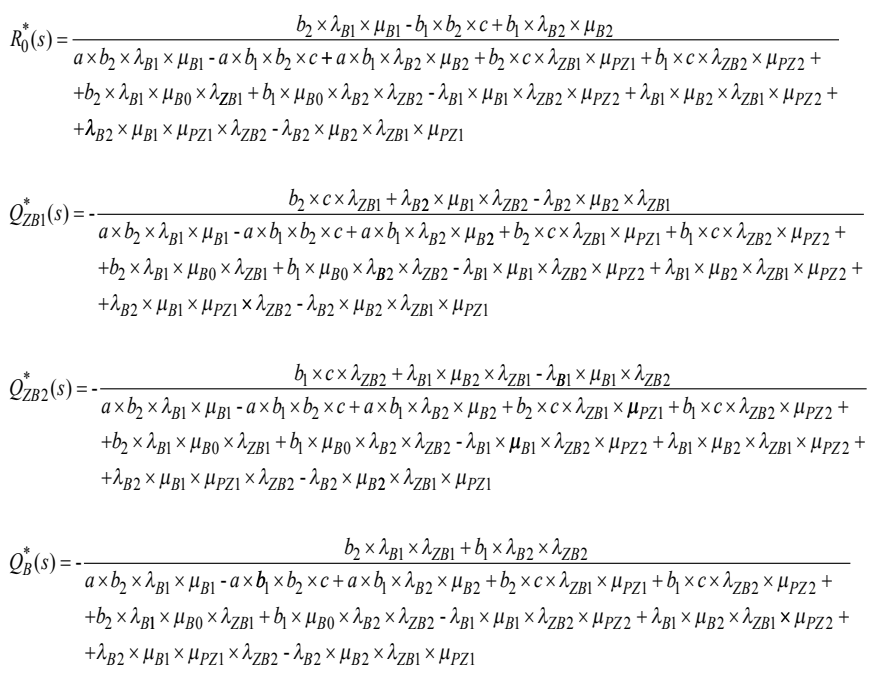

where:

$$
\begin{aligned}
& a=s+\lambda_{Z B 1}+\lambda_{Z B 2} \\
& b_{1}=s+\mu_{P Z 1}+\lambda_{B 1} \\
& b_{2}=s+\mu_{P Z 2}+\lambda_{B 2} \\
& c=s+\mu_{B 1}+\mu_{B 2}+\mu_{B 0}
\end{aligned}
$$

Solution to the above set of equations in the time domain is the next step in the analysis and is not discussed here.

\section{Modelling an operation process of an electronic transport system}

Computer simulation and computer-aided analysis facilitate to relatively quickly determine the influence of change in reliabilityexploitation parameters of individual components on reliability of the entire system. Of course, the reliability structure of both the entire system and its components has to be known beforehand.

Using computer aided allows to perform the calculation of the value of probability of system staying in state of full ability $R_{O}$. That procedure is illustrated with below example.

\section{Example}

The following quantities were defined for the system:

- test duration - 1 year (values of this parameter is given in [h]):

$$
\mathrm{t}=8760[h]
$$

- non-damageability of the system in the case electric field interference, with values in the permissible range:

$$
\mathrm{R}_{\mathrm{ZB} 1}(t)=0,949
$$

- non-damageability of the system in the case magnetic field interference, with values in the permissible range:

$$
\mathrm{R}_{\mathrm{ZB} 2}(t)=0,991
$$

- transition rate from the state of the impendency over safety $\mathrm{S}_{\mathrm{ZB} 1}$ into the state of unreliability of safety $\mathrm{S}_{\mathrm{B}}$ :

$$
\lambda_{B 1}=0,000001
$$

- transition rate from the state of the impendency over safety $\mathrm{S}_{\mathrm{ZB} 2}$ into the state of unreliability of safety $\mathrm{S}_{\mathrm{B}}$ :

$$
\lambda_{B 2}=0,000006
$$

- transition rate from the state of unreliability of safety $S_{B}$ into the state of full ability $\mathrm{S}_{\mathrm{PZ}}$ : 


$$
\mu_{B 0}=0,01
$$

- transition rate from the state of unreliability of safety $S_{B}$ into the state of the impendency over safety $\mathrm{S}_{\mathrm{ZB} 1}$ :

$$
\mu_{B 1}=0,1
$$

- transition rate from the state of unreliability of safety $S_{B}$ into the state of the impendency over safety $\mathrm{S}_{\mathrm{ZB} 2}$ :

$$
\mu_{B 2}=0,1
$$

Knowing the value of reliability $\mathrm{R}_{\mathrm{ZB} 1}(t)$, transition rate from the state of full ability into the state of the impendency over safety $S_{Z B 1}$ may be estimated. Provided the up time is described by exponential distribution, the following relationship can be used:

$$
\mathrm{R}_{\mathrm{ZB} 1}(\mathrm{t})=\mathrm{e}^{-\lambda_{\mathrm{ZB} 1} \mathrm{t}} \text { for } t \geq 0
$$

thus:

$$
\lambda_{\mathrm{ZB} 1}=-\frac{\ln \mathrm{R}_{\mathrm{ZB} 1}(\mathrm{t})}{\mathrm{t}}
$$

For $\mathrm{t}=8760[h]$ and $\mathrm{R}_{\mathrm{ZB} 1}(t)=0,949$ we obtain:

$$
\lambda_{\mathrm{ZB} 1}=-\frac{\ln \mathrm{R}_{\mathrm{ZB} 1}(\mathrm{t})}{\mathrm{t}}=-\frac{\ln 0,949}{8760}=0,000006\left[\frac{1}{\mathrm{~h}}\right]
$$

Knowing the value of reliability $\mathrm{R}_{\mathrm{ZB} 2}(t)$, transition rate from the state of full ability into the state of the impendency over safety $\mathrm{S}_{\mathrm{ZB} 2}$ may be estimated. Provided the up time is described by exponential distribution, the following relationship can be used:

$$
\mathrm{R}_{\mathrm{ZB} 2}(\mathrm{t})=\mathrm{e}^{-\lambda_{\mathrm{ZB} 2} \mathrm{t}} \text { for } t \geq 0
$$

thus:

$$
\lambda_{\mathrm{ZB} 2}=-\frac{\ln \mathrm{R}_{\mathrm{ZB} 2}(\mathrm{t})}{\mathrm{t}}
$$

For $\mathrm{t}=8760[h]$ and $\mathrm{R}_{\mathrm{ZB} 2}(t)=0,991$ we obtain:

$$
\lambda_{\mathrm{ZB} 2}=-\frac{\ln \mathrm{R}_{\mathrm{ZB} 2}(\mathrm{t})}{\mathrm{t}}=-\frac{\ln 0,991}{8760}=0,000001\left[\frac{1}{\mathrm{~h}}\right]
$$

For above initial values, by use of (4) equations, following results are obtained:

$$
\begin{aligned}
& 3,85003 \cdot 10^{11} \cdot s+3,3 \cdot 10^{11} \cdot \mu_{P Z 1}+5,5 \cdot 10^{10} \cdot \mu_{P Z 2}+5 \cdot 10^{17} \cdot s^{2} \cdot \mu_{P Z 1}+5 \cdot 10^{17} \cdot s^{2} \cdot \mu_{P Z 2}+ \\
& +1,050035 \cdot 10^{17} \cdot s^{2}+5 \cdot 10^{17} \cdot s^{3}+1,05003 \cdot 10^{17} \cdot s \cdot \mu_{P Z 1}+1,050005 \cdot 10^{17} \cdot s \cdot \mu_{P Z 2}+ \\
R_{0}^{*}(s)= & +1,05 \cdot 10^{17} \cdot \mu_{P Z 1} \cdot \mu_{P Z 2}+5 \cdot 10^{17} \cdot s \cdot \mu_{P Z 1} \cdot \mu_{P Z 2}+30000 \\
& 2,665021 \cdot 10^{6} \cdot s+1,050035 \cdot 10^{17} \cdot s^{2} \cdot \mu_{P Z 1}+1,050035 \cdot 10^{17} \cdot s^{2} \cdot \mu_{P Z 2}-5 \cdot 10^{17} \cdot s^{3} \cdot \mu_{P Z 1}+ \\
& +5 \cdot 10^{17} \cdot s^{3} \cdot \mu_{P Z 2}+1,1200275 \cdot 10^{12} \cdot s^{2}+1,05007 \cdot 10^{17} \cdot s^{3}+5 \cdot 10^{17} \cdot s^{4}+ \\
& +4,35003 \cdot 10^{11} \cdot s \cdot \mu_{P Z 1}+6,85003 \cdot 10^{11} \cdot s \cdot \mu_{P Z 2}+1,05 \cdot 10^{17} \cdot s \cdot \mu_{P Z 1} \cdot \mu_{P Z 2}+ \\
& +5 \cdot 10^{17} \cdot s^{2} \cdot \mu_{P Z 1} \cdot \mu_{P Z 2}
\end{aligned}
$$

Assuming $\mu_{P Z 1}=0,1, \mu_{P Z 2}=0,2$ and using the Laplace'a transformation we receive:

$R_{0}(t)=0,00000496942 \cdot e^{-0,199947319 \cdot t}+0,000059996 \cdot e^{-0,100006 \cdot t}+3,03804695 \cdot e^{-0,21006058 \cdot t}+$ $+0,9999350039$

Finally, we obtain:

$R_{O}=0,999935$

The presented reliability-operational analysis of an electronic transport system, taking into account electromagnetic interference, allows numerical assessment of different types of solutions (technical and organizational), which can be implemented in order to mitigate the impact of electromagnetic interference on the system's functioning.

In order to mitigate the impact of electromagnetic interference on electronic transport systems, we need to determine: the interference source, interference receiver and the manner of the source coupling with the receiver. There are three main ways to limit the manners, the interference spreads:

- interference may be suppressed at the source (e.g. use of protective screening),

- execution of an electronic transport system, which shall be insensitive to the interference impacting it, which are present in an electromagnetic environment (use of electronic elements executed with proper technology),

- minimizing the transfer of interference through coupling channels (e.g. decoupling filters, groundings, gate drives [16, 17], screening, etc.).

In conclusion, if the constructors know the conditions of the electromagnetic environment (e.g. through the above presented measurements and reliability-operational analyses), in which the electronic transport system will probably be functioning, then the EMC requirements need to be met, which are usually known and can be taken into account when developing the device's structure.

\section{Conclusion}

Widespread use of electric and electronic systems in electronic transport systems causes the need of them functioning in a variety of systems, while being located very close to each other. This may result in an increase of the probability of interference in the systems' functioning, thus, being in states of partial worthiness. That is why, when designing electronic transport systems, they need to be prepared for operation in real conditions, meaning, being surrounded by other devices. The presented methodology of reliability-operational analysis of electronic transport systems, taking into account electromagnetic interference, may be helpful in this case. It allows to specify with numbers the probability values of the system being in the distinguished states.

In further studies, the authors plan to differentiate the sates of partial worthiness and highlight their subordinate states. This will allow more thorough mapping of the function of an electronic transport system utilized in an electromagnetic environment. 


\section{References}

1. Billinton R, Allan RN. Reliability evaluation of power systems. New York: Plenum Press, 1996, https://doi.org/10.1007/978-1-48991860-4.

2. Burdzik R, Konieczny Ł, Figlus T. Concept of on-board comfort vibration monitoring system for vehicles. In the monograph Activities of Transport Telematics, editors: Mikulski J., TST 2013, CCIS 395. Heidelberg: Springer, 2013: 418-425, https://doi.org/10.1007/978-3-64241647-7_51.

3. Charoy A. Interference in electronic equipment. Warsaw: WNT, 1999.

4. Dabrowski T, Bednarek M, Fokow K, Wisnios M. The method of threshold-comparative diagnosing insensitive on disturbances of diagnostic signals. Przeglad Elektrotechniczny - Electrical Review 2012; 88(11A):93-97.

5. Duer S, Zajkowski K, Duer R, Paś J. Designing of an effective structure of system for the maintenance of a technical object with the using information from an artificial neural network. Neural Computing \& Applications 2012; 23(3): 913-925, https://doi.org/10.1007/s00521-0121016-0.

6. Dyduch J, Paś J, Rosiński A. The basic of the exploitation of transport electronic systems. Radom: Publishing House of Radom University of Technology, 2011.

7. Garmabaki A.H.S., Ahmadi A., Mahmood Y.A., Barabadi A. Reliability modelling of multiple repairable units. Quality and Reliability Engineering International 2016; 32(7): 2329-2343, https://doi.org/10.1002/qre.1938.

8. Jacyna-Gołda I. Evaluation of operational reliability of the supply chain in terms of the control and management of logistics processes. In Safety and Reliability: Methodology and Applications - Proceedings of the European Safety and Reliability Conference ESREL 2014, editors: Nowakowski T., Młyńczak M., Jodejko-PietruczukA. \&Werbińska-Wojciechowska S. London: CRC Press/Balkema, 2015: 549558.

9. Kasprzyk Z, Rychlicki M. Analysis of phiysical layer model of WLAN 802.11g data transmission protocol in wireles networks used by telematic systems. In: Proceedings of the Ninth International Conference Dependability and Complex Systems DepCoS-RELCOMEX, given as the monographic publishing series - Advances in intelligent systems and computing", vol. 286. Springer, 2014: 265-274.

10. Lewiński A, Perzyński T, Torun A. The analysis of open transmission standards in railway control and management. Communications in Computer and Information Science, vo. 329. Berlin Heidelberg: Springer-Verlag, 2012: 10-17.

11. Łubkowski P, Laskowski D. Selected issues of reliable identification of object in transport systems using video monitoring services. Communication in Computer and Information Science, vol. 471. Berlin Heidelberg, Springer, 2015: 59-68.

12. Ogunsola A, Mariscotti A. Electromagnetic compatibility in railways. Analysis and management. Springer-Verlag, 2013, https://doi. org/10.1007/978-3-642-30281-7.

13. Ott HW. Electromagnetic compatibility engineering. Wiley, 2009, https://doi.org/10.1002/9780470508510.

14. Paś J, Duer S. Determination of the impact indicators of electromagnetic interferences on computer information systems. Neural Computing \& Applications 2012; 23(7): 2143-2157, https://doi.org/10.1007/s00521-012-1165-1.

15. Paś J. Operation of electronic transportation systems. Radom: Publishing House University of Technology and Humanities, 2015.

16. Perlicki K. Evaluation of the spatial distribution of birefringence in an optical-fiber link. Microwave and Optical Technology Letters 2004; 42 (2): 147-149, https://doi.org/10.1002/mop.20234.

17. Perlicki K. Impact of an alien wavelength on wavelength division multiplexing transmission quality. Photonics Letters of Poland 2012; 4(3): 118-120, https://doi.org/10.4302/plp.2012.3.12.

18. Perzyński T, Lewiński A, Łukasik Z. Safety analysis of accidents call system especially related to in-land water transport based on new telematic solutions. Communications in Computer and Information Science, Tools of Transport Telematics, vol 531. Berlin Heidelberg: Springer-Verlag, 2015: 90-98

19. Rosiński A. Modelling the maintenance process of transport telematics systems. Warsaw: Publishing House Warsaw University of Technology, 2015.

20. Siergiejczyk M, Krzykowska K, Rosiński A. Reliability assessment of cooperation and replacement of surveillance systems in air traffic. In: Proceedings of the Ninth International Conference Dependability and Complex Systems DepCoS-RELCOMEX, editors: W. Zamojski, J. Mazurkiewicz, J. Sugier, T. Walkowiak, J. Kacprzyk, given as the monographic publishing series - Advances in intelligent systems and computing", vol. 286. Springer, 2014: 403-411, https://doi.org/10.1007/978-3-319-07013-1_39.

21. Siergiejczyk M, Krzykowska K, Rosiński A. Reliability assessment of integrated airport surface surveillance system. In: Proceedings of the Tenth International Conference on Dependability and Complex Systems DepCoS-RELCOMEX, editors: W.Zamojski, J. Mazurkiewicz, J. Sugier, T. Walkowiak, J. Kacprzyk, given as the monographic publishing series - Advances in intelligent systems and computing", vol. 365. Springer, 2015: 435-443, https://doi.org/10.1007/978-3-319-19216-1_41.

22. Siergiejczyk M, Paś J, Rosiński A. Train call recorder and electromagnetic interference. Diagnostyka 2015; 16(1): 19-22.

23. Siergiejczyk M, Paś J., Rosiński A. Issue of reliability-exploitation evaluation of electronic transport systems used in the railway environment with consideration of electromagnetic interference. IET Intelligent Transport Systems 2016; 10(9): 587-593, https://doi.org/10.1049/ietits.2015.0183.

24. Siergiejczyk M, Paś J., Rosiński A. Modeling of process of exploitation of transport telematics systems with regard to electromagnetic interferences. In Tools of Transport Telematics, editors: Mikulski J., given as the monographic publishing series - Communications in Computer and Information Science", vol. 531. Berlin Heidelberg: Springer-Verlag, 2015: 99-107.

25. Siergiejczyk M, Rosiński A, Krzykowska K. Reliability assessment of supporting satellite system EGNOS. In the monograph New results in dependability and computer systems, editors: W. Zamojski, J. Mazurkiewicz, J. Sugier, T. Walkowiak, https://doi.org/10.1007/978-3-31900945-2_32.

26. Siergiejczyk M, Rosiński A. Analysis of power supply maintenance in transport telematics system. Solid State Phenomena 2014; 210: 14-19, https://doi.org/10.4028/www.scientific.net/SSP.210.14.

27. Skorupski J, Uchroński P. A fuzzy reasoning system for evaluating the efficiency of cabin luggage screening at airports. Transportation Research Part C - Emerging Technologies 2015; 54: 157-175, https://doi.org/10.1016/j.trc.2015.03.017.

28. Stawowy M, Dziula P. Comparison of uncertainty multilayer models of impact of teleinformation devices reliability on information quality. 
In: Proceedings of the European Safety and Reliability Conference ESREL 2015, editors: Podofillini L., Sudret B., Stojadinovic B., Zio E., Kröger W. CRC Press/Balkema, 2015: 2685-2691, https://doi.org/10.1201/b19094-351.

29. Stawowy M. Model for information quality determination of teleinformation systems of transport. In: Proceedings of the European Safety and Reliability Conference ESREL 2014, editors: Nowakowski T., Młyńczak M., Jodejko-Pietruczuk A., Werbińska-Wojciechowska S. CRC Press/Balkema, 2015: 1909-1914.

30. Sumiła M., Miszkiewicz A. Analysis of the problem of interference of the public network operators to GSM-R. In Tools of Transport Telematics, editors: Mikulski J., given as the monographic publishing series - Communications in Computer and Information Science", vol. 531. Berlin Heidelberg: Springer-Verlag, 2015: 76-82, https://doi.org/10.1007/978-3-319-24577-5_25.

31. Verma AK, Ajit S, Karanki DR. Reliability and safety engineering. London: Springer, 2010, https://doi.org/10.1007/978-1-84996-232-2.

32. Weintrit A., Dziula P., Siergiejczyk M., Rosiński A. Reliability and exploitation analysis of navigational system consisting of ECDIS and ECDIS back-up systems. The monograph Activities in Navigation - Marine Navigation And Safety Of Sea Transportation, editors: Weintrit A. London: CRC Press/Balkema, 2015: 109-115, https://doi.org/10.1201/b18513-17.

\author{
Jacek PAŚ \\ Military University of Technology \\ Faculty of Electronics \\ Institute of Electronic Systems \\ Division of Electronic Systems Exploitations \\ gen. S. Kaliskiego 2, 00-908 Warsaw, Poland \\ Adam ROSIŃSKI \\ Warsaw University of Technology \\ Faculty of Transport \\ Department of Telecommunications in Transport \\ Koszykowa 75, 00-662 Warsaw, Poland \\ E-mails: jacek.pas@wat.edu.pl ,adro@wt.pw.edu.pl
}

